\title{
NITROGEN BALANCE IN SOIL UNDER EUCALYPTUS PLANTATIONS $^{(1)}$
}

\author{
Patrícia Anjos Bittencourt Barreto ${ }^{(2)}$, Antonio Carlos da Gama-Rodrigues ${ }^{(3)}$, Emanuela \\ Forestieri da Gama-Rodrigues ${ }^{(4)}$ \& Nairam Félix de Barros ${ }^{(5)}$
}

\begin{abstract}
SUMARY
An understanding of the role of organic nitrogen $(\mathrm{N})$ pools in the $\mathrm{N}$ supply of eucalyptus plantations is essential for the development of strategies that maximize the efficient use of $\mathbf{N}$ for this crop. This study aimed to evaluate the distribution of organic $\mathbf{N}$ pools in different compartments of the soil-plant system and their contributions to the $N$ supply in eucalyptus plantations at different ages $(1,3,5$, and 13 years). Three models were used to estimate the contributions of organic pools: Model I considered $\mathbf{N}$ pools contained in the litterfall, $\mathbf{N}$ pools in the soil microbial biomass and available soil $\mathbf{N}$ (mineral $\mathbf{N}$ ); Model II considered the $\mathbf{N}$ pools in the soil, potentially mineralizable $N$ and the export of $N$ through wood harvesting; and Model III ( $\mathrm{N}$ balance) was defined as the difference between the initial soil $N$ pool $(0-10 \mathrm{~cm})$ and the export of $N$, taking the application of $N$ fertilizer into account. Model I showed that $N$ pools could supply $27-70 \%$ of the $N$ demands of eucalyptus trees at different ages. Model II suggested that the soil $\mathrm{N}$ pool may be sufficient for 4 - 5 rotations of 5 years. According to the $N$ balance, these $N$ pools would be sufficient to meet the $N$ demands of eucalyptus for more than 15 rotations of 5 years. The organic pools contribute with different levels of $\mathbf{N}$ and together are sufficient to meet the $\mathbf{N}$ demands of eucalyptus for several rotations.
\end{abstract}

Index terms: microbial biomass $\mathrm{N}$, potentially mineralizable $\mathrm{N}$, microbial cycling.

(1) Received publication in November 26, 2010 and approved in June 5, 2012.

(2) Assistant Professor, Soil and Agricultural Engineering Department, State University of Southwest Bahia, CEP 45031-300 Vitória da Conquista (BA). E-mail: patriciabarreto@uesb.edu.br

(3) Full Professor, Soil Laboratory, North Fluminense State University, CEP 28013-602 Campos dos Goytacazes (RJ). E-mail: tonygama@uenf.br

(4) Associate Professor, Soil Laboratory, North Fluminense State University, CEP 28013-602 Campos dos Goytacazes (RJ). Email: emanuela@uenf.br

(5) Full Professor, Soil Department, Federal University of Viçosa - UFV. CEP 36570-000 Viçosa (MG). E-mail: nfbarros@.ufv.br 


\title{
RESUMO: BALANÇO DE N EM SOLOS SOB PLANTAÇÕES DE EUCALIPTO
}

\begin{abstract}
O entendimento da participação de reservas orgânicas de $N$ no suprimento de plantações de eucalipto é fundamental para o desenvolvimento de estratégias que maximizem a eficiência no uso de $N$ por essa cultura. $O$ objetivo deste trabalho foi avaliar a distribuição de reservas orgânicas de $N$ em diferentes compartimentos no sistema solo-planta e a contribuição desses compartimentos no suprimento de $N$ em plantações de eucalipto em diferentes idades de cultivo (1, 3, 5 e 13 anos). Para estimar a contribuição das reservas orgânicas, foram empregados três modelos: o modelo I considerou os estoques do $N$ contido na serapilheira e na biomassa microbiana do solo e o $N$ disponível no solo ( $N$ mineral); o modelo II considerou os estoques de $N$ no solo, o $N$ potencialmente mineralizável e a exportação de $N$ na colheita da madeira; $e o$ modelo III (balanço de $N$ ) foi definido pela diferença entre o estoque inicial de $N$ no solo (0-10 $\mathrm{cm}$ ) e a exportação de $N$, somada a uma aplicação de fertilizante nitrogenado. $O$ modelo $I$ mostrou que as reservas de $N$ poderiam suprir de 27 a $70 \%$ da demanda de $N$ pelo eucalipto entre as idades. $O$ modelo II mostrou que o estoque de $N$ no solo pode ser suficiente para quatro a cinco rotações de cinco anos. Pelo balanço de $N$, o estoque de $N$ seria suficiente para suprir a demanda desse nutriente pelo eucalipto por mais de 15 rotações de cinco anos. As reservas orgânicas contribuem para ofornecimento de Nem diferentes magnitudes e, em conjunto, são suficientes para atender à demanda de $N$ pelo eucalipto por várias rotações de cultivo.
\end{abstract}

Termos de indexação: $N$ da biomassa microbiana, $N$ potencialmente mineralizável, ciclagem microbiana.

\section{INTRODUCTION}

In Brazil, the high demand for forest products has led to a progressive increase in planted forests, which currently occupy an area of 6.5 million hectares. Among the species planted, eucalyptus is the most widely grown, occupying approximately 4.26 million hectares, an area corresponding to $66 \%$ of the planted forest in the country (SBS, 2009).

Mineral fertilization promotes substantial productivity gains in most eucalyptus forests (Barros \& Novais, 1990; Gonçalves et al., 1997; Barros et al., 2000), constituting a fundamental step for the establishment and development of trees as well as the maintenance of yields over subsequent rotations. However, in Brazil, the $\mathrm{N}$ fertilization of these plantations is usually based on generalized NPK formulations, regardless of the actual amount of $\mathrm{N}$ that should be applied. This situation arises partially from the inability to predict the actual $\mathrm{N}$ contribution of the soil (Pulito, 2009).

Gonçalves et al. (1996) recommended that the $\mathrm{N}$ fertilization of eucalyptus plantations be based on three classes of soil organic matter (SOM) content. However, although SOM is the primary source of soil N, this type of recommendation does not consider the bioavailability of this nutrient. Bioavailability is regulated not only by the SOM quantity and quality but also by climate and edaphic factors and by forest management (Cantarella \& Raij, 1986).

In this context, the efficient management of $\mathrm{N}$ fertilization in planted forests, e.g., eucalyptus plantations, requires the quantification of the various $\mathrm{N}$ input and output flows in the soil-plant system, and nutrient cycling and harvest export must be taken into consideration to plan the management appropriately. Litterfall deposition and subsequent release of $\mathrm{N}$, which is incorporated into the plant residues via mineralization, is a key process in $\mathrm{N}$ cycling and an important $\mathrm{N}$ source for trees (Gonçalves, 1995; Camargo et al., 1999; Alfaia, 2006).

In areas newly forested with eucalyptus, the mineralization of organic $\mathrm{N}$ pools can meet the demand of trees throughout the crop cycle (O'Connell \& Rance, 1999; Gonçalves et al., 2001; Gonçalves et al., 2008; Barreto et al., 2010). In these areas, approximately $75 \%$ of $\mathrm{N}$ is contained in the harvest residues (Santana et al., 2008). Therefore, plant responses to $\mathrm{N}$ fertilizers are often small or even negligible (Barros et al., 1990; Hebert \& Schönau, 1989; Gonçalves et al., 1997).

The N-mineralization process is mediated by soil microbial biomass (MB), which controls $\mathrm{N}$ availability through the balance of immobilization-mineralization processes (Vargas \& Scholles, 1998; Gama-Rodriguez et al., 2005). Thus, the MB is an active and potentially mineralizable compartment of soil N (Bonde et al., 1988; Gama-Rodrigues et al., 2005) and plays a key role in the availability of this element. Recent studies suggest that the cycling of $\mathrm{N}$ stored in the MB can supply eucalyptus with a considerable amount of $\mathrm{N}$ (Gama-Rodriguez et al., 2005; Barreto et al., 2008) since the cycling of this compartment is faster than of the other SOM fractions (Smith \& Paul, 1990).

Estimates of the amount of inorganic $\mathrm{N}$ that can be released into the soil due to mineralization and the amount of mineral $\mathrm{N}$ that can be made available from MB through microbial cycling, along with estimates 
of the $\mathrm{N}$ quantities stored in the soil, in the litterfall and in the biomass of eucalyptus plantations, are essential to define the $\mathrm{N}$ balance in these ecosystems. Such estimates can improve the understanding of $\mathrm{N}$ dynamics and support the development of strategies to maximize the efficiency of $\mathrm{N}$ use by eucalyptus plantations.

This study was designed to assess the distribution of organic $\mathrm{N}$ pools in different compartments of the soil-plant system by three models and estimate the contributions of these compartments to the $\mathrm{N}$ supply of eucalyptus plantations at different ages $(1,3,5$ and 13 years).

\section{MATERIAL AND METHODS}

\section{Study areas}

The study was conducted in several commercial eucalyptus plantations located in Aracruz, in the coastal region of Espirito Santo ( $19^{\circ} 50^{\prime} \mathrm{S}, 40^{\circ} 03^{\prime} \mathrm{W}$ ). The regional terrain is flat, the soil mediumtextured, classified as dystrophic Yellow Argisolic (Embrapa, 2006), and the climate humid tropical (Aw), according to Köppen's classification, with an average annual temperature of $23^{\circ} \mathrm{C}$ and pluvial precipitation of $1,400 \mathrm{~mm}$.

Eucalyptus plantations were selected based on age and crop rotation, covering an age sequence $(1,3,5$ and 13 years) using the reform system. The plant material (clone 1501, "Urograndis"), spacing (3x $3 \mathrm{~m}$ ) and soil class and texture were the same in all plantations. The history of tillage and fertilization used in the eucalyptus plantations, as well as the soil chemical properties, were described by Barreto et al. (2008).

\section{Collection and analysis of plant biomass}

Plant material was sampled in November 2003. At each plantation age, four plots $(18 \times 18 \mathrm{~m}$, with 36 trees spaced $3 \times 3 \mathrm{~m}$ ) were established. On each plot, a tree with an average diameter at breast height (DBH $=4,12,15$ and $20 \mathrm{~cm}$ in the plantations of $1,3,5$ and 13 years, respectively) was selected, and litterfall was collected from a $3 \times 3 \mathrm{~m}$ area around this tree. Subsequently, the selected trees were cut and harvested to quantify aboveground biomass (leaves, branches, bark, and wood).

The plant biomass (dry matter) of the tree components was determined based on biomass samples of leaves, branches, bark and wood (approximately $1 \mathrm{~kg}$ of each component) that were oven-dried to constant weight at $60^{\circ} \mathrm{C}$ (Embrapa, 1999). The dried samples were chopped and subjected to chemical analysis for the determination of $\mathrm{N}$ levels, using the Kjeldahl method as described by Bataglia et al. (1983).

\section{Soil collection of soil and mineral $\mathrm{N}$ analysis}

Soil samples were collected in November 2003. From the same plots used for collection of plant biomass, composite soil samples (composed of 20 single samples) were collected with a Dutch auger $(0-10 \mathrm{~cm})$. Undisturbed samples were also collected with volumetric rings for determination of soil density.

For mineral $\mathrm{N}$ extraction a $50 \mathrm{~g}$ soil sample was mixed with an equal amount of washed and sieved sand, and the mixture placed in percolation columns (PVC tubes, diameter $4 \mathrm{~cm} \times$ height $30 \mathrm{~cm}$ ). Glass wool plugs had been placed at the bottom of each percolator. Mineral $\mathrm{N}$ was extracted by percolating $100 \mathrm{~mL}$ of $0.01 \mathrm{~mol} \mathrm{~L}^{-1} \mathrm{CaCl}_{2}$ (extraction solution), applied in $20 \mathrm{~mL}$ fractions, through the samples in the percolation tubes.

Soil $\mathrm{N}$ mineral $\left(\mathrm{N}-\mathrm{NH}_{4}{ }^{+}+\mathrm{N}^{-} \mathrm{NO}_{3}{ }^{-}\right)$was determined using $20 \mathrm{~mL}$ of the percolate filtered through a fine paper filter to remove particulate matter. The N-NH${ }_{4}{ }^{+}$ and $\mathrm{N}-\mathrm{NO}_{3}{ }^{-}$contents were evaluated by colorimetry in a continuous flow system (FIA) (Giné et al., 1980; Alves et al., 1993).

\section{Microbial biomass and $\mathbf{N}$ mineralization}

The data for microbial biomass $\mathrm{N}$ and $\mathrm{N}$ mineralization were obtained from Barreto et al. (2008) and Barreto et al. (2010), respectively, from data compiled from the same study areas as those analyzed in this study. Barreto et al. (2008) used the fumigationextraction method to estimate soil microbial biomass N (Joergensen \& Brookes, 1990). Barreto et al. (2010) adopted the laboratory aerobic incubation technique, proposed by Stanford \& Smith (1972), to determine the soil $\mathrm{N}$ mineralization potential $\left(\mathrm{N}_{\mathrm{o}}\right)$.

\section{$\mathbf{N}$ pools in the soil}

Nitrogen pools in the soils were calculated by the following expression:

$\mathrm{N}_{\mathrm{S}}=(\mathrm{Nt} * \mathrm{Ds} * \mathrm{Th})$

where $\mathrm{N}_{\mathrm{S}}$ represents soil $\mathrm{N}$ pool $\left(\mathrm{kg} \mathrm{ha}^{-1}\right)$; $\mathrm{Nt}$, the total content of $\mathrm{N}$ in the soil $\left(\mathrm{g} \mathrm{kg}^{-1}\right)$, from Barreto et al. (2008); Ds, soil density $\left(\mathrm{kg} \mathrm{dm}^{-3}\right)$; and Th, the thickness of the analyzed layer $(0-10 \mathrm{~cm})$. The soils had densities of $1.27 ; 1.34 ; 1.41$ and $1.44 \mathrm{~kg} \mathrm{dm}^{-3}$ in the 1, 3, 5 and 13 -year-old plantations, respectively.

\section{Contribution of organic $\mathrm{N}$ pools}

To estimate the contributions of organic pools to the $\mathrm{N}$ supply in eucalyptus plantations, three models (Model I, Model II and N balance) were used:

\section{Model I}

This model was applied to all plantations studied. $\mathrm{N}$ pools contained in the litterfall, $\mathrm{N}$ pools in the soil microbial biomass and mineral $\mathrm{N}$ in the $0-10 \mathrm{~cm}$ layer were considered. To calculate the contribution of $\mathrm{N}$ 
pools (NP\%) present in these compartments to the $\mathrm{N}$ supply, it was necessary to estimate the microbial cycling, the $\mathrm{N}$ flow of the microbial biomass, $\mathrm{N}$ supply $\mathrm{N}$ from litterfall and $\mathrm{N}$ demand by eucalyptus trees at different ages. Thus, in this model, the prediction of the pools and their contributions were assessed by the following expressions (2 to 6):

$\mathrm{MC}=\mathrm{NMB} /\left(\mathrm{N}_{\mathrm{LF} \text { year }}+43 \%\right.$ of $\left.\mathrm{N}_{\mathrm{abs}}\right)$

Flow $\mathrm{NMB}=\mathrm{NMB} / \mathrm{CM}$

$\mathrm{N}_{\text {supplied litterfall }}=\mathrm{N}_{\mathrm{LF} \text { accumulated }} * 0.4$

$\mathrm{NR}=\mathrm{NMB}$ Flow $\mathrm{N}+\mathrm{N}_{\text {supplied litterfall }}+$ Mineral $\mathrm{N}$

$\% \mathrm{RN}=\mathrm{RN} * 100 / \mathrm{ND}$

where $\mathrm{MC}$ is the microbial cycling in years; NMB is the $\mathrm{N}$ content of soil microbial biomass $\left(\mathrm{kg} \mathrm{ha}^{-1}\right)$; $\mathrm{N}_{\mathrm{LF} \text { year }}$ represents $\mathrm{N}$ input in the soil through plant residues left on the surface, corresponding to the average increase of $\mathrm{N}$ in the accumulated litterfall of the plantations per year $\left(20 \mathrm{~kg} \mathrm{ha}^{-1}\right.$ year $\left.^{-1}\right) ; \mathrm{N}_{\mathrm{abs}}$ is the amount of $\mathrm{N}$ absorbed by eucalyptus ( $\mathrm{N}$ accumulated in the aboveground biomass of trees per year) (kg ha-1); NMB Flow is the $\mathrm{N}$ flow of soil microbial biomass $\left(\mathrm{kg} \mathrm{ha}^{-1}\right.$ year $\left.^{-1}\right) ; \mathrm{N}_{\text {supplied litterfall }}$ is $\mathrm{N}$ supplied by litterfall ( $\mathrm{kg} \mathrm{ha}^{-1}$ ), assuming a $40 \%$ decomposition rate; $\mathrm{N}_{L F \text { cumulative }}$ is the amount of $\mathrm{N}$ contained in the litterfall $\left(\mathrm{kg} \mathrm{ha}^{-1}\right)$; $\mathrm{NR}$ is the $\mathrm{N}$ pool in the compartments analyzed by Model I ( $\left.\mathrm{kg} \mathrm{ha}^{-1}\right) ; \% \mathrm{NR}$ is the NR contribution for the $\mathrm{N}$ demand by trees among the ages or up to the age assessed; and ND is the N demand of eucalyptus trees $\left(\mathrm{kg} \mathrm{ha}^{-1}\right)$. The formula used (2) was proposed by Smith \& Paul (1990).

The $40 \%$ decomposition rate used for the calculation of $\mathrm{N}_{\text {supplied litterfall }}$ represents the arithmetic average of the following different decomposition rates found in the literature for eucalyptus: Ferreira (1984), in Eucalyptus grandis in approximately 6-year-old plantations (50\%); Gama-Rodrigues \& Barros (2002), in Eucalyptus grandis / E. urophylla in 16-year-old plantations (40\%); and Costa et al. (2005), in Eucalyptus grandis in 2,5 and 8-year-old plantations $(30 \%)$. Several studies indicate that the decomposition rates of eucalyptus forests are typically below $50 \%$ throughout the year under a number of different management practices and edaphoclimatic conditions (Adams \& Attiwill, 1986; Louzada et al., 1997; GamaRodrigues \& Barros, 2002; Costa et al., 2005).

The demand for $\mathrm{N}$ was estimated for 1 year and for age intervals, considering the amount of $\mathrm{N}$ absorbed by the crop and the $\mathrm{N}$ contained in the litterfall at each age, as proposed by Gama-Rodrigues (1997), according to the following expressions:

$\mathrm{ND}=\mathrm{N}_{\mathrm{LF} 1}+\mathrm{N}_{\mathrm{PB} 1}$

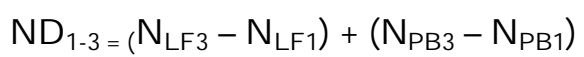

$\mathrm{ND}_{3-5}=\left(\mathrm{N}_{\mathrm{LF} 5}-\mathrm{N}_{\mathrm{LF} 3}\right)+\left(\mathrm{N}_{\mathrm{PB} 5}-\mathrm{N}_{\mathrm{PB} 3}\right)$

$\mathrm{ND}_{5-13}=\left(\mathrm{N}_{\mathrm{LF} 13}-\mathrm{N}_{\mathrm{LF} 5}\right)+\left(\mathrm{N}_{\mathrm{PB} 13}-\mathrm{N}_{\mathrm{PB} 5}\right)$ where $\mathrm{ND}$ is the $\mathrm{N}$ demand $\left(\mathrm{ND}_{1}=\mathrm{ND}\right.$ up to 1 year of age, $\mathrm{ND}_{1-3}=\mathrm{ND}$ between the ages of 1 and 3 years, $\mathrm{ND}_{3-5}=\mathrm{ND}$ between 3 and 5 years, $\mathrm{ND}_{5-13}=$ between 5 and 13 years); $\mathrm{N}_{\mathrm{LF} 1}, \mathrm{~N}_{\mathrm{LF} 3}, \mathrm{~N}_{\mathrm{LF} 5}$ and $\mathrm{N}_{\mathrm{LF} 13}$ are the amounts of $\mathrm{N}$ contained in the accumulated litterfall of the 1, 3, 5 and 13-year-old plantations, respectively; $\mathrm{N}_{\mathrm{PB} 1}, \mathrm{~N}_{\mathrm{PB} 3}, \mathrm{~N}_{\mathrm{PB} 5}$ and $\mathrm{N}_{\mathrm{PB} 13}$ are the amounts of $\mathrm{N}$ contained in the aboveground plant biomass of the 1 , 3,5 and 13-year-old plantations, respectively.

The participation of $\mathrm{N}$ Flow supplied by the soil microbial biomass in the flow of potentially mineralized $\mathrm{N}$ in the soil was calculated, considering an estimate of mineralized $\mathrm{N}$ per year $\left(\mathrm{kg} \mathrm{ha}^{-1}\right.$ year $\left.{ }^{-1}\right)$, using the following equation:

$\%$ Flow NMB $=($ NMB Flow $* 100) / \mathrm{N}_{\mathrm{o}}$

\section{Model II}

This model considered the total $\mathrm{N}$, the potentially mineralizable $\mathrm{N}\left(\mathrm{N}_{\mathrm{o}}\right)(0-10 \mathrm{~cm}$ depth$)$ and the export of $\mathrm{N}$ due to wood harvesting. The model estimated the duration (in number of crop rotations) of the soil $\mathrm{N}$ pools. This model was applied only to plantations of 5 and 13 years of age, here considered as cutting age (crop rotation). For this purpose, $\mathrm{N}_{\mathrm{o}}$ was considered an estimate of mineralized $\mathrm{N}$ per year. Moreover, it was assumed that the $\mathrm{N}$ values stored in the tree wood (Table 1) corresponded to the amount of $\mathrm{N}$ exported. In this model, the prediction of $\mathrm{N}$ supplied

Table 1. Above-ground biomass and $N$ content from different compartments of eucalyptus in an age sequence

\begin{tabular}{|c|c|c|c|c|}
\hline \multirow{2}{*}{ Component } & \multicolumn{4}{|c|}{ Age (years) } \\
\hline & $\mathbf{1}$ & $\mathbf{3}$ & $\mathbf{5}$ & 13 \\
\hline & \multicolumn{4}{|c|}{ Above-ground biomass $\left(\mathrm{Mg} \mathrm{ha}^{-1}\right)$} \\
\hline Bark & $0.4 \mathrm{~d}^{(1)}$ & $8.0 \mathrm{c}$ & $13.4 \mathrm{~b}$ & $24.8 \mathrm{a}$ \\
\hline Leaves & $2.5 \mathrm{a}$ & $2.6 \mathrm{a}$ & $2.1 \mathrm{ab}$ & $1.84 \mathrm{~b}$ \\
\hline Branches & $2.3 \mathrm{~b}$ & $3.2 \mathrm{~b}$ & $2.6 \mathrm{~b}$ & $8.9 \mathrm{a}$ \\
\hline Wood & $2.1 \mathrm{~d}$ & $38.5 \mathrm{c}$ & $85.2 \mathrm{~b}$ & $252.8 \mathrm{a}$ \\
\hline Litter $^{(2)}$ & $1.6 \mathrm{~d}$ & $3.8 \mathrm{c}$ & $15.3 \mathrm{~b}$ & $22.9 \mathrm{a}$ \\
\hline \multirow[t]{2}{*}{ Total } & 8.8 & 56.1 & 118.6 & 311.2 \\
\hline & \multicolumn{4}{|c|}{$\mathbf{N}$ content $\left(\mathrm{kg} \mathrm{ha}^{-1}\right)$} \\
\hline Bark & $1.6 \mathrm{~d}$ & $30.2 \mathrm{c}$ & $55.1 \mathrm{~b}$ & $99.8 \mathrm{a}$ \\
\hline Leaves & $50.2 \mathrm{~b}$ & $66.0 \mathrm{a}$ & $41.7 \mathrm{c}$ & $35.5 \mathrm{c}$ \\
\hline Branches & $11.9 \mathrm{~b}$ & $15.8 \mathrm{~b}$ & $12.6 \mathrm{~b}$ & $44.3 \mathrm{a}$ \\
\hline Wood & $5.0 \mathrm{~d}$ & $67.5 \mathrm{c}$ & $110.7 \mathrm{~b}$ & $309.7 \mathrm{a}$ \\
\hline Litter ${ }^{(2)}$ & $20.3 \mathrm{~d}$ & $33.9 \mathrm{c}$ & $102.0 \mathrm{~b}$ & $224.0 \mathrm{a}$ \\
\hline Total & 89.0 & 213.4 & 322.1 & 713.3 \\
\hline
\end{tabular}

(1) Means followed by the same letter in a row do not differ by Duncan test at $5 \%$; ${ }^{(2)}$ Data from Barreto et al. (2008). 
by the mineralization process over a number of rotations $(\mathrm{Nr})$ for the eucalyptus plantations was based on Gonçalves et al. $(2000,2001)$ and Barreto et al. (2010), according to the expressions (12) and (13):

$\mathrm{Nr}=\mathrm{Nt} /\left(\mathrm{Q}+\mathrm{N}_{\mathrm{ex}}\right)$

$\mathrm{Q}=\mathrm{N}_{\mathrm{o}} * \mathrm{r}$

where $\mathrm{Nr}$ is the duration of the soil $\mathrm{N}$ pools in number of rotations; $\mathrm{Nt}$ is the total soil $\mathrm{N}$ pools in the $0-10 \mathrm{~cm}$ layer $\left(\mathrm{kg} \mathrm{ha}^{-1}\right)$; $\mathrm{Q}$ is the amount of $\mathrm{N}$ mineralized per rotation $\left(\mathrm{kg} \mathrm{ha}^{-1}\right) ; \mathrm{N}_{\mathrm{x}}$ is the amount of $\mathrm{N}$ exported by cutting (via debarked wood) at the end of each rotation $\left(\mathrm{kg} \mathrm{ha}^{-1}\right) ; \mathrm{N}_{\mathrm{o}}$ is the potentially mineralizable $\mathrm{N}$ in the $0-10 \mathrm{~cm}^{2}$ layer $\left(\mathrm{kg} \mathrm{ha}^{-1}\right.$ year-1); and $r$ is the crop rotation in years.

\section{N balance}

The $\mathrm{N}$ balance (NB) was defined as the difference between the initial soil $\mathrm{N}$ pools $(0-10 \mathrm{~cm})\left(\mathrm{N}_{\mathrm{S}}\right)$ and the export of $\mathrm{N}\left(\mathrm{N}_{\mathrm{ex}}\right)$, with an application of $\mathrm{N}$ fertilizer $\left(\mathrm{F}=40 \mathrm{~kg} \mathrm{ha}^{-1}\right)$, with a $50 \%$ use efficiency rate (Gonçalves et al., 2001) was also taken into account. From this result, the predicted duration of the NB pools in number of rotations $\left(\mathrm{Nr}_{\mathrm{BN}}\right)$ was obtained through the relationship between NB and the $\mathrm{N}$ demand for the rotation considered (NDr). This model was also applied to plantations of 5 to 13 years of age only, using the expressions (14) and (15):

$\mathrm{NB}=\left(\mathrm{N}_{\mathrm{s}}-\mathrm{N}_{\mathrm{ex}}\right)+\mathrm{F}$

$\mathrm{Nr}_{\mathrm{NB}}=\mathrm{NB} / \mathrm{NDr}$

\section{Statistical analysis}

The data on the amount of plant biomass and $\mathrm{N}$ pools were analyzed using a completely randomized design with four replications. A $5 \% \mathrm{~F}$ test was adopted. As a complement, the Duncan test was used to compare means at $5 \%$ probability. A Pearson correlation ( $5 \%$ ) was established between the NMB data of Barreto et al. (2008), and the $\mathrm{N}_{\mathrm{o}}$ data from Barreto et al. (2010).

\section{RESULTS AND DISCUSSION}

\section{Plant biomass and $\mathbf{N}$ pool}

The amounts of plant biomass and $\mathrm{N}$ content accumulated in the different components of the aboveground parts of eucalyptus trees from each plantation are presented in table $1 . \mathrm{N}$ accumulation in these trees reflected the pattern of plant biomass accumulation, highlighting the close relationship between $\mathrm{N}$ absorption and biomass production (Poggiani et al., 1983; Poggiani, 1985; Reis et al., 1987; Santana et al., 1999; Gonçalves et al., 2000).

There was a reduction in the $\mathrm{N}$ content per unit biomass with increasing age. Furthermore, there was a decrease in the $\mathrm{N}$ leaf content of three and more year-old trees (Table 1), demonstrating the intensification of biochemical cycling and increase in $\mathrm{N}$ use efficiency for eucalyptus production with increasing age. As the tree matures, an increasingly significant proportion of $\mathrm{N}$ demand is supplied by the biochemical cycle (Attiwill, 1980), and this is one of the main factors influencing the efficiency of nutrient use by eucalyptus as age increases (Reis \& Barros, 1990; Ladeira, 1999).

\section{One-year-old Eucalyptus}

To achieve a total biomass production of $8.8 \mathrm{Mg}$ ha $^{-1}$ (aboveground parts + litterfall) up to 1 year of age, eucalyptus showed an $\mathrm{N}$ demand of $89 \mathrm{~kg} \mathrm{ha}^{-1}$. At this age, the leaves and accumulated litterfall were equivalent to $4 \mathrm{mg} \mathrm{ha}^{-1}$, corresponding to more than $40 \%$ of the total biomass (Table 1). These components contain $79 \%$ of the $\mathrm{N}$ pools of the total biomass, representing the most important pathway of the biogeochemical cycle (Caldeira et al., 1999) and highlighting the important role of $\mathrm{N}$ return through litterfall deposition, decomposition and nutrient release for reabsorption by plant roots. The importance of this cycle has been demonstrated in forests growing on low fertility soils (Schumacher et al., 2003).

\section{Three-year-old Eucalyptus}

At this age, the eucalyptus plant biomass increased by $47 \mathrm{mg} \mathrm{ha}^{-1}$ compared to the one year old plantation, with an increase of $\mathrm{N}$ of $128 \mathrm{~kg} \mathrm{ha}^{-1}$ (Table 1). Of the total aboveground biomass, $68 \%$ is found in the wood $\left(38.5 \mathrm{mg} \mathrm{h}^{-1}\right)$; however, $47 \%$ of $\mathrm{N}$ pool is distributed in the leaves (31\%) and litterfall (16\%) (Table 1). The $\mathrm{N}$ content of the litterfall is equivalent to $51 \%$ of the $\mathrm{N}$ content in the leaves, which indicates that $49 \%$ of the $\mathrm{N}$ was retranslocated before senescence. In addition, the apparent decrease in the annual $\mathrm{N}$ demand up to this age suggests an increase in biochemical cycling and, consequently, $\mathrm{N}$ efficiency use by eucalyptus trees.

\section{Five-year-old Eucalyptus}

The leaves, branches, bark and litterfall components totaled to $33.4 \mathrm{mg} \mathrm{ha}^{-1}$, corresponding to $28 \%$ of the total biomass. These components, recycled via organic matter decomposition, contain $67 \%$ of the $\mathrm{N}$ pool of the total biomass. This result is in agreement with findings of Gonçalves (1995), who showed that in Eucalyptus grandis plantations in the State of São Paulo, on average age between 5 and 6 years old, these components contained $69.5 \%$ of the $\mathrm{N}$ of the aboveground biomass. Bark and litterfall contained nearly $50 \%$ of the pools of this nutrient. This finding shows the importance of adopting a management system that involves the return of harvest residues to minimize decreases in soil organic matter and, in turn, of $\mathrm{N}$ content. Cutting eucalyptus after 5 years and removing the wood would cause result in an $\mathrm{N}$ 
export of approximately $111 \mathrm{~kg} \mathrm{ha}^{-1}$ from the site, corresponding to $34 \%$ of the $\mathrm{N}$ pools in the aboveground forest biomass.

Compared to the age of 3 years, 5 -year-old eucalyptus trees needed only $106 \mathrm{~kg} \mathrm{ha}^{-1} \mathrm{~N}$ (Table 1 ), demonstrating increased $\mathrm{N}$ use efficiency due to intensification of the internal cycling process (biochemistry). This result was corroborated by the $\mathrm{N}$ leaf contents of each plantation (Table 1), which decreased from the levels of the 3 -year-old plantations.

\section{Thirteen- year-old Eucalyptus}

The total leaves, branches, bark and litterfall components was $58.4 \mathrm{mg} \mathrm{ha}^{-1}, 19 \%$ of the total biomass. These components contained $56 \%$ of the aboveground $\mathrm{N}$ pool, of which $45 \%$ was contained in the bark and litterfall. At the age of 13 years, eucalyptus trees are is in a more advanced maturity stage, and much of the absorbed $\mathrm{N}$ is derived from the decomposition of forest residues accumulated on the soil (Poggiani, 1985). At this age, the plant biomass of the trees had increased by $193 \mathrm{mg} \mathrm{ha}^{-1}$ compared to the age of 5 years, requiring an additional $391.2 \mathrm{~kg}$ ha $^{-1} \mathrm{~N}$ (Table 1$)$.

\section{Microbial biomass $\mathbf{N}$ vs. potentially mineralizable $\mathbf{N}$}

There was a significant positive correlation of the potentially mineralizable soil $\mathrm{N}\left(\mathrm{N}_{\mathrm{o}}\right)$ with the $\mathrm{N}$ content of the soil microbial biomass (NMB) at different ages $(r=0.9547, p<0.05)$ (Table 2$)$, which highlights the important role of the microbial component in the control of $\mathrm{N}$ availability through immobilization and mineralization processes (Vargas \& Scholles, 1998).
It is possible that the differences of $\mathrm{N}$ content in $\mathrm{N}_{\mathrm{o}}$ and NMB among the different age groups were related to the growth stages of the plantations. The values of $\mathrm{N}_{0}$ and NMB increased from the age of 1 to 3 years, then decreased until 5 years and increased again until 13 years (Table 2). In the first year of crop rotation, during crown formation, $\mathrm{N}$ demand is very high, and soil N pools consequently decrease (Silva, 1999; Gonçalves et al., 2000). Between 2 to 3 years of age, the increments of $\mathrm{N}$ and biomass decrease (Gonçalves et al., 1997), and the amount of mineralized soil $\mathrm{N}$ is usually high, especially when the harvest residues are left in the field (Smethurst \& Nambiar, 1995), explaining the increase in potentially mineralizable $\mathrm{N}$ in plantations from 1 to 3 years of age (Table 2). Moreover, according to Miller (1995), when the canopy closes, approximately $2 / 3$ of the nutritional demands of the plantation can be covered by nutrient redistribution (biogeochemical cycle), thereby decreasing the pressure on soil $\mathrm{N}$ pools. The decrease of $\mathrm{N}$ content in leaves of three and more yearold seedlings (Table 1) corroborates this information.

As the trees grow older, their $\mathrm{N}$ demand increases, and $\mathrm{N}$ mineralization becomes a limiting factor, as the entire amount of mineralized $\mathrm{N}$ is used by the system (Fölster \& Khana, 1997). Thus, the reduction of potentially mineralizable $\mathrm{N}$ at the age of 5 years (Table 2) must be related with increased $\mathrm{N}$ demand, while the increase of $\mathrm{N}_{0}$ after this age (Table 2) may be associated with larger increments of plant residues to the litterfall. These residues provided substantial increases in the amount of substrate for the activity of microorganisms, increasing the $\mathrm{N}$ mineralization potential of 13-year-old trees.

Proportions of $1.0 ; 1.1 ; 1.2$ and 0.9 were obtained for plantations at the ages of $1,3,13$ and 5 years,

Table 2. Nitrogen pools and microbial nitrogen turnover in the 0-10 cm layer and N demand for eucalyptus in an age sequence

\begin{tabular}{|c|c|c|c|c|}
\hline \multirow{2}{*}{ Nitrogen pool } & \multicolumn{4}{|c|}{ Age (years) } \\
\hline & 1 & 3 & 5 & 13 \\
\hline $\mathrm{N}_{\mathrm{s}}(0-10 \mathrm{~cm})\left(\mathrm{kg} \mathrm{ha}^{-1}\right)^{(1)}$ & 1890.2 & 2698.0 & 2538.0 & 2592.1 \\
\hline Soil mineral N $\left(\mathrm{kg} \mathrm{ha}^{-1}\right)$ & 26.4 & 31.7 & 28.8 & 34.7 \\
\hline $\mathrm{N}_{\mathrm{o}}(0-10 \mathrm{~cm})\left(\mathrm{kg} \mathrm{ha}^{-1} \text { year }^{-1}\right)^{(2)}$ & 98.0 & 127.4 & 81.6 & 109.6 \\
\hline $\mathrm{Nm}\left(\mathrm{kg} \mathrm{ha}^{-1}\right)^{(2)}$ & 74.7 & 93.8 & 68.3 & 81.9 \\
\hline NMB $(0-10 \mathrm{~cm})\left(\mathrm{kg} \mathrm{ha}^{-1}\right)^{(1)}$ & 76.2 & 105.5 & 61.8 & 101.1 \\
\hline Microbial cycling (MC) (years) & 1.5 & 2.4 & 1.7 & 2.9 \\
\hline Soil microbial biomass flux (kg ha $1 /$ years) & 49.5 & 44.6 & 36.3 & 35.1 \\
\hline NMB contribution to the flow of mineral $\mathrm{N}(\%)$ & 50.6 & 35.0 & 44.4 & 32.0 \\
\hline $\mathrm{N}$ demand of eucalyptus trees $\left(\mathrm{kg} \mathrm{ha}^{-1}\right)^{(3)}$ & 89.0 & 127.8 & 105.5 & 391.2 \\
\hline Total $\mathrm{N}$ demand of eucalyptus trees $\left(\mathrm{kg} \mathrm{ha}^{-1}\right)^{(4)}$ & 89.0 & 216.8 & 322.3 & 713.3 \\
\hline
\end{tabular}

Ns: N stock; No: Potentially mineralizable; N; Nm: mineralized N; NMB: N microbial biomass. 
respectively, for the ratio of $\mathrm{NMB}$ contents by the amounts of mineralized $\mathrm{N}(\mathrm{Nm})$ (Table 2) (NMB:Nm ratio). The microbial biomass can function as a catalyst, a source and/or a drain of nutrients (Paul \& Clark, 1989; Wardle, 1992). When acting as a drain, the amount of nutrients supplied via mineralization is less than that entering the system. As a source, the nutrient amount released is greater than that entering the system, and as a catalyst, the input and output amounts are equal (Gama-Rodrigues, 1999). Thus, based on the NMB:Nm ratio, the microbial biomass at the age of 1 year would be acting as a catalyst (NMB: $\mathrm{Nm}=1)$, at the ages of 3 and 13 years as a drain (NMB:Nm $>1$ ) and at the age of 5 years as a source (NMB: Nm < 1). These results demonstrate the dynamic role of $\mathrm{MB}$ in the potential supply of $\mathrm{N}$ throughout the growth cycle of the eucalyptus crop. Gama-Rodrigues et al. (1997) observed an inverse correlation of soil $\mathrm{N}$ microbial biomass with mineral $\mathrm{N}$ in a Red-Yellow Latosol under different forest covers, showing that in eucalyptus and pine plantations without $\mathrm{N}$ fertilization, the soil microbial biomass, in addition to being a catalyst, would also act as an $\mathrm{N}$ drain.

\section{Microbial cycling}

The values of microbial $\mathrm{N}$ cycling in soils under eucalyptus plantations ranged from 1.5 to 2.9 years, and the $\mathrm{N}$ flow supplied by the microbial biomass was between 35 and $50 \mathrm{~kg} \mathrm{ha}^{-1}$ year-1 $^{-1}$ (Table 2). At different eucalyptus forest sites, Gama-Rodrigues (1997) observed microbial cycling from 0.54 to 1.36 years and $\mathrm{N}$ flows of microbial biomass from 40 to $98 \mathrm{~kg} \mathrm{ha}^{-1}$ year $^{-1}$.

\section{Contribution of $\mathbf{N}$ pools}

\section{Model I}

\section{One-year-old Eucalyptus}

As the litterfall can provide $8 \mathrm{~kg} \mathrm{ha}^{-1} \mathrm{~N}, \mathrm{~N}$ flow generated by the microbial biomass corresponds to $50 \mathrm{~kg} \mathrm{ha}^{-1}$ year $^{-1}$ in the $0-10 \mathrm{~cm}$ soil layer and the soil has a mineral $\mathrm{N}$ pool of $26 \mathrm{~kg} \mathrm{ha}^{-1}$ (Table 2), eucalyptus at the age of 1 year would contain a total $\mathrm{N}$ pool of $84 \mathrm{~kg} \mathrm{ha}^{-1}$. These $\mathrm{N}$ pools would be sufficient to meet approximately $66 \%$ of the $\mathrm{N}$ demand of eucalyptus from the age of 1 until 3 years (Table 2 ).

Based on the potentially mineralizable $\mathrm{N}$ in the soil at 1 year of age, the $\mathrm{N}$ flow supplied by the microbial biomass contributed with approximately $50 \%$ of the flow of soil mineralized N (Table 2). This result is in agreement with that reported by Bonde et al. (1988), who observed that $55-89 \%$ of mineralized $\mathrm{N}$ was derived from microbial biomass in soils cultivated with annual crops (cereals), which highlights the significant participation of this soil compartment in $\mathrm{N}$ supply.

\section{Three-year-old Eucalyptus}

At the age of 3 years, the litterfall and the soil can provide 14 to $32 \mathrm{~kg} \mathrm{ha}^{-1}$ of mineral $\mathrm{N}$, respectively, and the microbial biomass can provide an $\mathrm{N}$ flow of $45 \mathrm{~kg} \mathrm{ha}^{-1}$ year $^{-1}$. Considering these compartments, the soil $\mathrm{N}$ pool would be sufficient to meet all $\mathrm{N}$ demands of eucalyptus from 3 up to 5 years, and the $\mathrm{N}$ flow supplied by the soil microbial biomass would be responsible for $70 \%$ of the supply of this element for eucalyptus until the age of 5 years (Table 2 ).

The $\mathrm{N}$ flow generated by the microbial compartment represents $35 \%$ of the flow of soil mineralized $\mathrm{N}$, based on the potentially mineralizable $\mathrm{N}$ of the soil under the age of 3 years.

\section{Five-year-old Eucalyptus}

At the age of 5 years, the litterfall can provide 41 $\mathrm{kg} \mathrm{ha}^{-1} \mathrm{~N}$, the soil can provide $29 \mathrm{~kg} \mathrm{ha}^{-1}$ of mineral $\mathrm{N}$ and the microbial biomass can provide an $\mathrm{N}$ flow

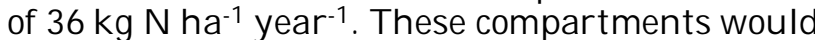
be sufficient to meet approximately $27 \%$ of the $\mathrm{N}$ demand of eucalyptus from 5 to 13 years of age (Table 2). The flow of microbial $\mathrm{N}$ accounted for 44 $\%$ of the flow of mineralized $\mathrm{N}$ in the soil, based on the potentially mineralizable $\mathrm{N}$ of the soil under the age of 5 years.

If a crop rotation of 5 years (cutting age) is assumed, the $\mathrm{N}$ requirement of eucalyptus trees for a yield of $103 \mathrm{mg} \mathrm{ha}^{-1}$ would be $322 \mathrm{~kg} \mathrm{ha}^{-1} \mathrm{~N}$, and the $\mathrm{N}$ export in the debarked wood would be $111 \mathrm{~kg} \mathrm{ha}^{-1}$ rotation of $\mathrm{N}$. Considering the $\mathrm{N}$ accumulated in the litterfall until this age (Table 1) and in the post-harvest residues left on the field, the amount of $\mathrm{N}$ released (decomposition rate $40 \%$ ) would correspond to 125 $\mathrm{kg} \mathrm{ha}^{-1}$. Considering that the microbial biomass also contributed with an $\mathrm{N}$ flow of $36 \mathrm{~kg} \mathrm{ha}^{-1}$ and that the soil has a mineral $\mathrm{N}$ pool of $29 \mathrm{~kg} \mathrm{ha}^{-1}$, these $\mathrm{N}$ compartments should be sufficient to meet more than $50 \%$ of the $\mathrm{N}$ demand of the following crop rotation (5 years).

\section{Thirteen-year-old Eucalyptus}

Considering the $\mathrm{N}$ flow of soil microbial biomass of 13 -year-old trees $\left(35 \mathrm{~kg} \mathrm{ha}^{-1}\right.$ year $\left.^{-1}\right)$ and the $90 \mathrm{~kg}$ $\mathrm{ha}^{-1} \mathrm{~N}$ released from the litterfall, the $\mathrm{N}$ supply made available by only these two compartments would be approximately $125 \mathrm{~kg} \mathrm{~h}^{-1}$ of $\mathrm{N}$, representing $40 \%$ of the amount of $\mathrm{N}$ export in debarked wood (Table 2). Based on the potentially mineralizable $\mathrm{N}$ of the soil under 13-year-old trees, the $\mathrm{N}$ flow supplied by the microbial biomass would contribute with $32 \%$ of mineralized $\mathrm{N}$ in the soil.

\section{Model II}

\section{Five-year-old Eucalyptus}

Taking into consideration the initial soil $\mathrm{N}$ pools, the $\mathrm{N}$ demand of eucalyptus until the age of 5 years and the $\mathrm{N}$ export of $111 \mathrm{~kg} \mathrm{ha}^{-1} /$ rotation (5 years), it was estimated that the $\mathrm{N}$ pools in the $0-10 \mathrm{~cm}$ soil layer would be sufficient for 4 to 5 eucalyptus rotations (Table 2). 


\section{Thirteen-year-old Eucalyptus}

Assuming $\mathrm{N}$ export of $310 \mathrm{~kg} \mathrm{ha}^{-1} /$ rotation, the $\mathrm{N}$ pools in the $0-10 \mathrm{~cm}$ soil layer were estimated to be sufficient for another 2 to 3 eucalyptus rotations (13 years).

\section{N balance}

Using the $\mathrm{N}$ balance based on 13 and 5 year-oldplantations, and leaving all forest residues on the soil, the harvest of debarked wood and the application of $\mathrm{N}$ fertilizer ( $40 \mathrm{~kg} \mathrm{ha}^{-1} \mathrm{~N}$, at $50 \%$ use efficiency), it was estimated that the average soil $(0-10 \mathrm{~cm}) \mathrm{N}$ pool of $2,565 \mathrm{~kg} \mathrm{ha}^{-1}$ was sufficient to meet the $\mathrm{N}$ demands of eucalyptus for more than 7 rotations of 13 years and over 15 rotations of 5 years.

The integrated analysis of different compartments of organic $\mathrm{N}$ pools appears to be an appropriate method to estimate $\mathrm{N}$ availability for the eucalyptus crop and can improve $\mathrm{N}$ fertilizer recommendations. Furthermore, the results indicate the relevant contributions of the microbial biomass to $\mathrm{N}$ supply because it is part of the potentially mineralizable soil N (Bonde et al., 1988; Gama-Rodrigues et al., 2005).

Future studies should analyze subsequent crop rotations, sampling larger volumes of soil (down to 1 $\mathrm{m}$ depth), to provide more detailed insights into the adequacy of the methodology used in this work; due to the high rates of $\mathrm{N}$ export (Barros et al., 1990; Poggiani, 1985; Reis et al., 1987; Gonçalves, 1995), there is a possibility of depletion of organic potentially mineralizable N. Research on this subject is still very scarce in other countries with forestry traditions, but particularly in Brazil (Serrano, 1997; Gonçalves et al., 2001; Pulito, 2009; Barreto et al., 2010).

\section{CONCLUSIONS}

1. The organic pools contribute to the $\mathrm{N}$ supply at different levels, and together they are sufficient to meet the $\mathrm{N}$ demands of eucalyptus for several crop rotations, especially in low fertility areas.

2. Among the organic pools, the microbial biomass flow can contribute with more than half of the potentially mineralizable soil $\mathrm{N}$ under eucalyptus cultivation.

\section{LITERATURE CITED}

ADAMS, M.A. \& ATTIWILL, P.M. Nutrient cycling and nitrogen mineralization in eucalypt forests south-easthern Australia. I. Nutrient cycling and nitrogen turnover. Plant Soil, 92:319-339, 1986.

ALFAIA, S.S. Caracterização e distribuição das formas do nitrogênio orgânico em três solos da Amazônia Central. Acta Amaz., 36:135-140, 2006.
ALVES, B.J.R.; BODDEY, R.M. \& URQUIAGA, S.A. Rapid and sensitive flow injection technique for the analysis of ammonium in soil extracts. Comm. Soil Sci. Plant Anal., 24:277-284, 1993.

ATTIWILL, P.M. Nutrient cycling in a Eucalyptus obliqua forest: IV - Nutrient uptake and nutrient return. Austr. J. Bot., 28:199-222, 1980.

BARRETO, P.A.B.; GAMA-RODRIGUES, E.F.; GAMARODRIGUES, A.C.; BARROS, N.F.; ALVES, B.J.R. \& FONSECA, S. Mineralização de nitrogênio e carbono em solos sob plantações de eucalipto, em uma sequência de idades. R. Bras. Ci. Solo, 34:735-745, 2010.

BARRETO, P.A.B.; GAMA-RODRIGUES. E.F.; GAMARODRIGUES, A.C.; BARROS, N.F. \& FONSECA, S. Atividade, carbono e nitrogênio da biomassa microbiana em plantações de eucalipto, em uma seqüência de idades. R. Bras. Ci. Solo, 32:611-619, 2008.

BARROS, N.F. \& NOVAIS, R.F. Relação solo-eucalipto. Viçosa, MG, Folha de Viçosa, 1990. 430p.

BARROS, N.F.; NEVES, J.C.L. \& NOVAIS, R.F. Recomendação de fertilizantes minerais em plantios de eucalipto. In: GONÇALVES, J.L.M. \& BENEDETT, V., eds. Nutrição e fertilização florestal. Piracicaba, IPEF, 2000. p.220-286.

BARROS, N.F.; NEVES, J.C.L. \& NOVAIS, R.F. Fertilização e correção do solo para o plantio de eucalipto. In: BARROS, N.F. \& NOVAIS, R.F., eds. Relação soloeucalipto. Viçosa, MG, Folha de Viçosa, 1990. p.127186.

BATAGLIA, O.C.; FURLANI, A.M.C.; TEIXEIRA, J.P.F.; FURLANI, P.R. \& GALLO, J.R. Métodos de análise química de plantas. Campinas, Instituto Agronômico de Campinas, 1983. 48p. (Boletim Técnico, 78).

BONDE, T.A.; SCHNÜRER, J. \& ROSSWALL, T. Microbial biomass as a fraction of potentially mineralizable nitrogen in soils from long-term field experiments. Soil Biol. Biochem., 20:447-452, 1988.

CALDEIRA, M.V.W.; PEREIRA, J.C.; SCHUMACHER, M.V.; DELLA-FLORA, J.B. \& SANTOS, E.M. Comparação entre as concentrações de nutrientes nas folhas e no folhedo em um povoamento de Acácia mernsii De Wild. R. Árvore, 23:489-492, 1999.

CAMARGO, F.A.O.; GIANELLO, C.; TEDESCO, M.J. \& VIDOR, C. Nitrogênio orgânico do solo. In: SANTOS, G.A. \& CAMARGO, F.A.O., eds. Fundamentos da matéria orgânica do solo: Ecossistemas tropicais e sub-tropicais. Porto Alegre, Gênesis, 1999. p.117-138.

CANTARELLA, H. \& RAIJ, B. van. Adubação nitrogenada no Estado de São Paulo. In: REUNIÃO BRASILEIRA DE FERTILIDADE DO SOLO, 16., Ilhéus 1985. Adubação nitrogenada no Brasil. Anais... Ilhéus: CEPLAC, 1986. p.47-79.

COSTA, G.S.; GAMA-RODRIGUES, A.C. \& CUNHA, G.M. Decomposição e liberação de nutrientes da serapilheira foliar em povoamentos de Eucalyptus grandis no Norte Fluminense. R. Árvore, 29:563-570, 2005. 
EMPRESA BRASILEIRA DE PESQUISA AGROPECUÁRIA EMBRAPA. Centro Nacional de Pesquisa de Solos. Sistema brasileiro de classificação de solos. 2.ed. Rio de Janeiro, 2006. 306p.

EMPRESA BRASILEIRA DE PESQUISA AGROPECUÁRIA EMBRAPA. Manual de análises químicas de solos, plantas e fertilizantes. Brasília, 1999. 370p.

FERREIRA, M.G.M. An analysis of the future productivity of Eucalyptus grandis plantations in the Cerrado region in Brazil: A nutrient cycling approach. Vancouver, University of Brishtish Columbia, 1984. 230p. (Tese de Doutorado)

FOLSTER, H. \& KHANNA, P.K. Dynamics of nutrient supply in plantation soils. In: NAMBIAR, E.K.S. \& BROWN, A.G., eds. Management of soil, nutrients and water in tropical plantation forests. Canberra, ACIAR, 1997. p.339-377.

GAMA-RODRIGUES, A.C. \& BARROS, N.F. Ciclagem de nutrientes em floresta natural e em plantios de eucalipto e de dandá no sudeste da Bahia, Brasil. R. Árvore, 26:193207, 2002.

GAMA-RODRIGUES, E.F. Biomassa microbiana e ciclagem de nutrientes. In: SANTOS, G.A. \& CAMARGO, F.A.O., eds. Fundamentos da matéria orgânica do solo: Ecossistemas tropicais e subtropicais. Porto Alegre, Gênesis, 1999. p.227-243.

GAMA-RODRIGUES, E.F. Carbono e nitrogênio da biomassa microbiana da serapilheira de povoamentos de eucalipto. Seropédica, Universidade Federal Rural do Rio de Janeiro, 1997. 108p. (Tese de Doutorado)

GAMA-RODRIGUES, E.F.; BARROS, N.F.; GAMARODRIGUES, A.C. \&. SANTOS, G.A. Nitrogênio, carbono e atividade da biomassa microbiana do solo em plantações de eucalipto. R. Bras. Ci. Solo, 29:393-901, 2005.

GAMA-RODRIGUES, E.F.; GAMA-RODRIGUES, A.C. \& BARROS, N.F. Biomassa microbiana de carbono e de nitrogênio de solos sob diferentes coberturas vegetais. $R$. Bras. Ci. Solo, 21:361-365, 1997.

GINÉ, M.F.; BERGAMIN FILHO, H.; ZAGATTO, E.A.G. \& REIS, B.F. Simultaneous determination of nitrate and nitrite by flow injection analysis. Anal. Chim. Acta, 114:191-197, 1980.

GONCCALVES, J.L.M. Efeito do cultivo mínimo sobre a fertilidade do solo e ciclagem de nutrientes. In: DISPERATI, A.A.; FERREIRA, C.A.; MACHADO, C.; GONÇALVES, J.L.M. \& SOARES, R.V., orgs. SEMINÁRIO SOBRE CULTIVO MÍNIMO DO SOLO EM FLORESTAS, 1., Curitiba, 1995. Anais... Curitiba, 1995. p.43-60.

GONÇALVES, J.L.M.; BARROS, N.F.; NAMBIAR, E.K.S. \& NOVAIS, R.F. Soil and stand management for shortrotation plantations. In: NAMBIAR, S. \& BROWN, A., eds. Management of soil, nutrients and water in tropical plantation forests. Canberra, ACIAR Austrália/CSIRO Austrália/CIFOR Indonésia, 1997. p.379-418.

GONCALVES, J.L.M.; MENDES, K.C.F.S. \& SASAKI, C.M. Mineralização de nitrogênio e carbono em ecossistemas florestais naturais e implantados no Estado de São Paulo. R. Bras. Ci. Solo, 25:601-616, 2001.
GONÇALVES, J.L.M.; RAIJ, B. van \& GONÇALVES, J.C. Florestais. In: RAIJ, B. van; CANTARELLA, H.; QUAGGIO, J.A. \& FURLANI, A.M.C., eds. Recomendações de adubação e calagem para o Estado de São Paulo. Campinas, Instituto Agronômico de Campinas e Fundação IAC, 1996. p.245-259.

GONÇALVES, J.L.M.; STAPE, J.L.; BENEDETT, V.; FESSEL, V.A.G. \& GAVA, J.L. Reflexos do cultivo mínimo e intensivo do solo em sua fertilidade e na nutrição das árvores. In: GONÇALVES, J.L.M. \& BENEDETT, V., eds. Nutrição e fertilização florestal. Piracicaba, IPEF, 2000. p.1-58.

GONÇALVES, J.L.M.; WICHERT, M.C.P.; GAVA, J.L. \& SERRANO, M.I.P. Soil fertility and growth of Eucalyptus grandis in Brazil under different residue management practices. In: NAMBIAR, E.K., ed. Site management and productivity in tropical plantation forests. Bogor, CIFOR, 2008. p.51-62.

JOERGENSEN, P.G. \& BROOKES, P.C. Ninhydrin-reactive nitrogen measurements of microbial biomass in $0,5 \mathrm{M}$ $\mathrm{K}_{2} \mathrm{SO}_{4}$ soil extracts. Soil Biol. Biochem., 22:1033-1027, 1990.

LADEIRA, B.C. Crescimento, produção de biomassa nutricional de Eucalyptus spp., sob três espaçamentos em uma seqüência de idades. Viçosa, MG, Universidade Federal de Viçosa, 1999. 132p. (Tese de Mestrado)

LOUZADA, J.N.C. et al. (AUTOR, COMPLETAR COM NOMES DOS OUTROS AUTORES, NÃO et al.) Litter decomposition in semidecidous Forest and Eucalyptus spp. Crop in Brazil: a comparison. For. Ecol. Manag., 94:3136, 1997.

MILLER, H.G. The influence of stand development on nutrient demand, growth and allocation. Plant Soil, 168-169:225232, 1995.

O'CONNELL, A.M. \& RANCE, S.J. Prediction nitrogen supply in plantation eucalypt forests. Soil Biol. Biochem., 31:19431951, 1999.

PAUL, E.A. \& CLARK, F.E. (eds). Soil microbiology and biochemistry. New York: Academic Press, 1989. 273p.

POGGIANI, F. Ciclagem de nutrients em ecossistemas de plantações de Eucalyptus e Pinus - Implicações silviculturais. Piracicaba, Escola Superior de Agricultura Luiz de Queiroz, 1985. 211p. (Tese de Doutorado)

POGGIANI, F.; COUTO, H.T.Z.; CORRADINI, L. \& FAZZIO, E.C.M. Exportação de biomassa e nutrientes através da exportação dos troncos e das copas de um povoamento de Eucalyptus saligna. R. IPEF, 25:37-39, 1983.

PULITO, A.P. Resposta à fertilização nitrogenada e estoque de nitrogênio biodisponível em solos usados para plantações de Eucalyptus. Piracicaba, Escola Superior de Agricultura Luiz de Queiroz, 2009. 58p. (Tese de Mestrado)

REIS, M.G.F. \& BARROS, N.F. Ciclagem de nutrientes em plantios de eucalipto. In: BARROS, N.F. \& NOVAIS, R.F., eds. Relação solo-eucalipto. Viçosa, MG, Folha de Viçosa, 1990. p.265-302. 
REIS, M.G.F.; BARROS, N.F. \& KIMMINS, J.P. Acúmulo de nutrientes em uma seqüência de idade de Eucalyptus grandis W. Hill (ex-maiden) plantado no Cerrado em duas áreas com diferentes produtividades, em Minas Gerais. R. Árvore, 11:1-15, 1987.

SANTANA, R.C.; BARROS, N.F. \& NEVES, J.C. Biomassa e conteúdo de nutrientes de procedências de Eucalyptus grandis e Eucalyptus saligna em alguns sítios florestais do Estado de São Paulo. Sci. For., 56:155-169, 1999.

SANTANA, R.C.; BARROS, N.F.; NOVAIS, R.F.; LEITE, H.G. \& COMERFORD, N.B. Alocação de nutrientes em plantios de eucalipto no Brasil. R. Bras. Ci. Solo, 32:2723-2733, 2008.

SCHUMACHER, M.V.; BRUN, E.J.; RODRIGUES, L.M. \& SANTOS, E.M. Retorno de nutrients via deposição da serapilheira em um povoamento de Acácia Negra (Acácia mernsii De Wild.) no Estado do Rio Grande do Sul. R. Árvore, 27:791-798, 2003.

SERRANO, M.I.P. Mineralização, absorção e lixiviação de nitrogênio, em povoamentos de Eucalyptus grandis sob cultivo mínimo e intensivo do solo. Piracicaba, Escola Superior de Agricultura Luiz de Queiroz, 1997. 85p. (Tese de Mestrado)
SILVA, L.F. Necessidade de adubação pós desbaste, baseada no balanço nutricional de povoamentos de eucalipto. Viçosa, MG, Universidade Federal de Viçosa, 1999. 62p. (Tese de Mestrado)

SMETHURST, P.J. \& NAMBIAR, E.K.S. Changes in soil carbon and nitrogen during the establishment of a second crop of Pinus radiata. For. Ecol. Manag., 73:145-155, 1995.

SMITH, J.L. \& PAUL, E.A. The significance of soil microbial biomass estimations. In: BOLLAG, J.M. \& STOTZKY, G., eds. Soil biochemistry. 1990. v.6. p.357-396.

SOCIEDADE BRASILEIRA DE SILVICULTURA - SBS. Disponível em: <http://www.sbs.org.br/destaques_florestaplantada.html>. Acessado em 06 out. de 2009.

STANFORD, G. \& SMITH, S.J. Nitrogen mineralization potentials of soils. Soil Sci. Soc. Am. J., 36:465-472, 1972.

VARGAS, L.K. \& SCHOLES, D. Nitrogênio da biomassa microbiana, em solo sob diferentes sistemas de manejo, estimado por métodos de fumigação. R. Bras. Ci. Solo, 22:411-417, 1998.

WARDLE, D.A. A comparative assessment of factors which influence microbial biomass carbon and nitrogen levels in soil. Biol. Rev., 67:21-358, 1992. 